$\overline{\text { ARTí́CULOS }}$ 



\title{
AUTORÍA Y CORPORATIVISMO EN LAS REALIZACIONES CINEMATOGRÁFICAS DE ERMANNO OLMI PARA LA EDISON VOLTA \\ (1953-1961) ${ }^{1}$
}

\author{
Authorship and Corporatism in the Cinematographic Productions \\ of Ermanno Olmi for the Edison Volta (1953-1961) \\ Gabriel Doménech GonZÁlez ${ }^{\mathrm{a}}$ \\ Universidad Carlos III de Madrid \\ DOI: http://dx.doi.org/10.15366/secuencias2017.46.001
}

\begin{abstract}
RESUMEN
El director italiano Ermanno Olmi comenzó su carrera cinematográfica realizando películas para la empresa hidroeléctrica Edison Volta, de la que era empleado, durante los años cincuenta. Siguiendo las líneas teóricas de autores como Vizenz Hediger, Patrick Vonderau, Thomas Elsaesser, Paola Bonifazio o Elena Mosconi sobre cine industrial y sobre los primeros trabajos cinematográficos de Olmi, este artículo pretende matizar algunos de los paradigmas teóricos desde los que se ha abordado la producción cinematográfica de la Edison Volta, al tiempo que propone otras herramientas para investigar el vasto y poco considerado corpus de cine industrial.
\end{abstract}

Palabras clave: Ermanno Olmi, Edison Volta, cine industrial, cine de autor, comunicación corporativa, discurso.

[1] Los primeros impulsos de esta investigación se deben a las clases del profesor Franco Prono de la Università degli Studi di Torino. Por otra parte, mis pesquisas en torno al cine industrial olmiano se beneficiaron de la inestimable ayuda de Josetxo Cerdán y Carlos Muguiro, que muy amablemente me dieron acceso a materiales tan valiosos como difíciles de conseguir. También por ayudarme a encontrar todo tipo de películas, pero, sobre todo, por compartir entusiasmos hacia el cine italiano en general y hacia el de Olmi en particular, quiero mostrar un agradecimiento muy especial a Mirito Torreiro.

\section{ABSTRACT}

The Italian film director Ermanno Olmi began his cinematic career in the 1950s making promotional films for the hydroelectric company Edison Volta, where he was employed. Following the theoretical lines proposed by scholars such as Vizenz Hediger, Patrick Vonderau, Thomas Elsaesser, Paola Bonifazio or Elena Mosconi on industrial cinema and Olmi's first cinematic works, this paper aims to refute some of the theoretical frameworks from which the film production of Edison Volta has been approached. At the same time, this article proposes other tools to investigate the vast but disregarded corpus of industrial cinema.

Keywords: Ermanno Olmi, Edison Volta, industrial cinema, author cinema, corporate communication, discourse.

[a] Gabriel Doménech González es contratado predoctoral FPU en el departamento de Periodismo y Comunicación Audiovisual de la Universidad Carlos III de Madrid y miembro del grupo de investigación TECMERIN. Compagina sus estudios de Doctorado en Investigación en Medios de Comunicación con la docencia en la misma universidad desde 2017. Titulado en Máster en Investigación aplicada a Medios de Comunicación, su Trabajo de Fin de Máster «Un cineasta industrioso. Ermanno Olmi y sus inicios en el cortometraje industrial» recibió el I Premio Rocío Orsi (2016). E-mail: gdomenec@hum.uc3m.es. 
Introducción: Ermanno Olmi en la Edison Volta

Ermanno Olmi (Bérgamo, 1931) es de sobra conocido en nuestros días por ser uno de los grandes directores italianos vivos. Durante sus ya más de cincuenta años de carrera cinematográfica, ha cosechado galardones como la Palma de Oro en Cannes -por El árbol de los zuecos (L'albero degli zoccoli, 1978)- o el León de Oro en Venecia - por La leyenda del santo bebedor (La leggenda del santo bevitore, 1988)-, además del reconocimiento unánime de la crítica como uno de los cineastas fundamentales de la modernidad cinematográfica surgida durante los años sesenta del pasado siglo. Se le han dedicado homenajes y retrospectivas en festivales y filmotecas de todo el mundo. Lo que no se conoce tanto, al menos fuera de Italia, es la primera faceta que adoptó su trayectoria como director «a sueldo» de una de las más importantes empresas hidroeléctricas de Italia.

Y es que, con dieciocho años y tras la muerte de su padre, Ermanno Olmi se vio obligado a abandonar los estudios y a entrar a trabajar como operario en la empresa Edison Volta para ayudar al sustento de su familia, perteneciente a la clase obrera milanesa ${ }^{2}$. Las tempranas inquietudes artísticas del joven lombardo le llevan, primero, a participar en las actividades culturales recreativas fomentadas por la compañía, entre las cuales estaba el teatro y, después, a aceptar el encargo de sus patrones de filmar, con fines promocionales, educativos y publicitarios, las diferentes actividades de la empresa ${ }^{3}$. El entusiasmo de Olmi es tal que, al poco tiempo, se le encomienda crear dentro de la Edison una sección específica dedicada al cine, supervisada por él mismo y pertrechada con material más sofisticado (una cámara Arriflex de 35 mm., objetivos panorámicos...), formándose además una troupe de colaboradores fijos con la que acomete una serie de cortometrajes que serán su herramienta de aprendizaje en el oficio del cine. De la frenética actividad de la Sezione Cinema Edison Volta nacieron hasta cuarenta filmes, con los que Olmi fue consolidando su prestigio no ya en el ámbito del por entonces en alza «cine industrial o de empresa», sino en los círculos intelectuales y cinematográficos de Milán, lo que al poco tiempo le permitiría emprender una brillante carrera

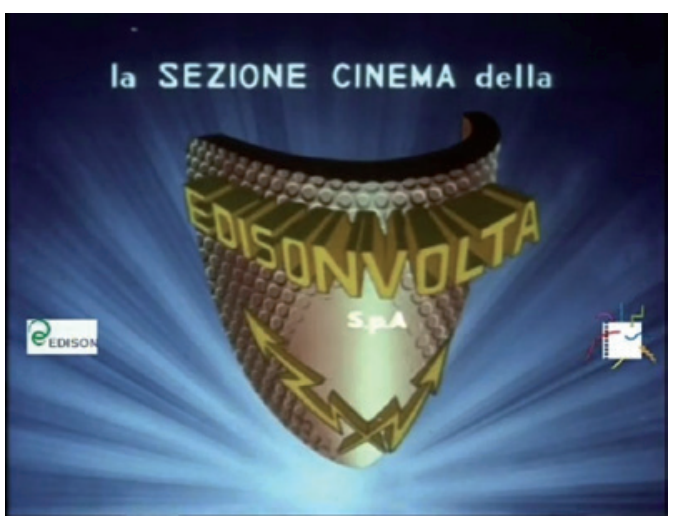

Imagen del logo de la Sezione Cinema Edison Volta, tomada del filme Un metro lungo cinque (Ermanno Olmi, 1961).
[2] La sociedad Edison Volta S.p.A. fue una empresa fundada en Milán en 1884 con el objetivo de producir y distribuir energía eléctrica. En los años siguientes a su creación conoció un rápido crecimiento, convirtiéndose en una de las principales eléctricas del país y primera en el área septentrional italiana. En los años cincuenta del siglo $\mathrm{xx}$ diversifica sus actividades: extracción de gas y petróleo, industria química... El presidente, en esta época, la misma en la que Olmi y su equipo figuraron en la nómina de empleados de la compañía, fue Vittorio De Biasi. La nacionalización del sector en 1963 obliga a transferir las actividades productivas y distributivas al grupo público Enel. Buscando reconfigurar su poder financiero, en 1966 se fusiona con la sociedad petroquímica Montecatini, creando a los tres años el grupo Montedison. La nueva sociedad cambiará su nombre a SELM en 1979, pero desde 1991 vuelve a la denominación original Edison, con la que continúa su actividad hasta nuestros días. El decreto Bersani de 1999 permitió la liberalización del sector eléctrico, con lo que Edison reemprendió sus antiguas funciones. Una OPA en 2001 integró el grupo Edison en un holding internacional en el que participa la eléctrica francesa EDF, entre otros. Además de en territorio italiano, la actual Edison mantiene actividad en Grecia y Francia.

[3] $\mathrm{Al}$ parecer, los superiores de Olmi, muy satisfechos tras asistir nado 4

a un montaje teatral dirigido por el joven operario, deciden regalarle una cámara de $16 \mathrm{~mm}$., un gesto que el crítico y teórico Alberto Farassino ha interpretado como una ostensible muestra de «viejo paternalismo empresarial» («Un metro di pellicola è lungo cinque: Ermanno Olmi alla Edisonvolta», en Alberto Farassino et al., Ermanno Olmi, dal cinema industriale al cinema d'autore [Milán, Obraz Cinestudio y Montedison, 1984], p. 4).

[4] Para una contextualización del floreciente panorama del cine industrial en Italia, que experimentó un fuerte auge a partir de los primeros años cincuenta paralelamente al crecimiento de la economía, véase Elena Mosconi, «Il film industriale» en Raffaele De Berti (ed.), Il cinema a Milano dal secondo dopoguerra ai primi anni sessanta. Número monográfico de Communicazioni Sociali, vol. XIII, n. ${ }^{0}$ 1-2, pp. 61-90. 
[5] Tullio Kezich, «Storia naturale di un piccolo miracolo», en Benedetta Tobagi (ed.), I volti e le mani. Ermanno Olmi. Gli anni Edison. Documentari e cortometraggi (1954-1959) (Milán, Giangiacomo Feltrinelli Editore, 2008), p. 68 (La traducción es nuestra).
Entre 1953, año del que datan sus primeras realizaciones, y 1961, cuando finaliza el cortometraje promocional Un metro lungo cinque (1961) y abandona definitivamente su puesto en la empresa hidroeléctrica, Ermanno Olmi va forjando una praxis y un estilo fílmicos muy sólidos. Algunos de los trabajos realizados durante esos años producen un gran impacto en ferias, festivales, congresos y otros ámbitos de recepción del cine corporativo. Filmes como $\mathrm{La}$ diga del ghiacciaio (1954), Manon finestra 2 (1956) o Tre fili fino a Milano (1958) introducen elementos argumentales, como el paulatino protagonismo de los obreros, la cotidianidad que permea el trabajo corporativo o el entorno natural donde no pocas veces se ambientan los esfuerzos industriales, que los diferencian del resto de la producción industrial del periodo. Además, Olmi y su troupe ponían en práctica métodos poco ortodoxos a la hora de facturar sus películas. Tullio Kezich, guionista y crítico, además de amigo y colaborador de Olmi - desde Un metro lungue cinque (1961), donde Kezich escribirá el texto didascálico-, relataba:

En general, [Olmi] no tenía las ideas claras sobre lo que debería rodar, sobre cuántos días duraría el rodaje o cuánto costaría. En las obras y en las fábricas curioseaba, hablaba con obreros y dirigentes, trataba de ambientarse. De vez en cuando empuñaba la cámara y filmaba una imagen, un personaje, un testimonio. [...] Apuntaba las cosas sobre la película sin tener en mente una «escaleta» narrativa. De vuelta, en Milán, el director pasaba y repasaba el material en la moviola [...]; en un momento dado, decidía recomenzar, rodaba algo nuevo y acumulaba material esperando que le llegase la iluminación, el hilo conductor. Para Un metro lungo cinque descubrió, en el último momento, a un tipo a quien le gustaba monologar [y le] invitó a improvisar con plena libertad fragmentos de alocución sobre varios temas. [...] A veces, la idea-guía tardaba en aparecer y el documental se quedaba parado durante largo tiempo ${ }^{5}$.

Esta metodología de trabajo introduce destellos de espontaneidad impensables en un ámbito considerado muy rígido como era el del cine promovido por industrias, lo que no impide la enorme consideración que se tenía a los filmes de la Edison. Las perspectivas abiertas por su labor al frente de la Sezione Cinema son, por tanto, enormemente halagüeñas para Olmi. Llegado un cierto punto, el realizador se anima a buscar nuevos horizontes creativos. Así, un proyecto de cortometraje promocional sobre las medidas de seguridad en las presas hidráulicas de la Edison Volta, iniciado en 1959, se convierte en el primer largometraje de ficción de su director, Il tempo si è fermato. Presentado en el Festival de Venecia de ese mismo año, su éxito y sus buenas críticas permiten a Olmi y a varios de sus colaboradores alejarse del área de influencia de su «empresa nodriza» para llevar adelante otros proyectos por vías progresivamente independientes. Los dos siguientes filmes de Olmi, El empleo (Il posto, 1961) e I fidanzati (1963), cosecharon un éxito crítico parecido al largometraje precedente. Además, proseguían una misma línea temática: la indagación, de índole (neor)realista, en las consecuencias y contradicciones del boom económico italiano, focalizándose en el universo laboral de la empresa moderna. 
Precisamente esta coincidencia temática ha hecho a muchos críticos y analistas agrupar estas tres películas bajo la denominación de «trilogía del trabajo» y ha conducido, además, a abordar el periodo previo de Olmi en la Edison Volta como un ensayo de los temas y formas presentes en esta producción, inserta ya en los circuitos del cine de autor destinado a festivales y salas comerciales ${ }^{6}$.

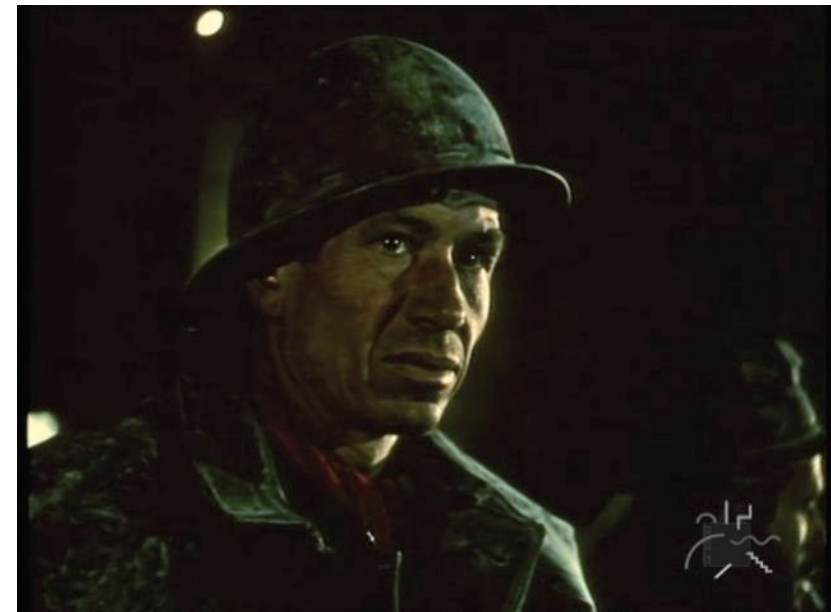

Manon Finestra 2 (1956).

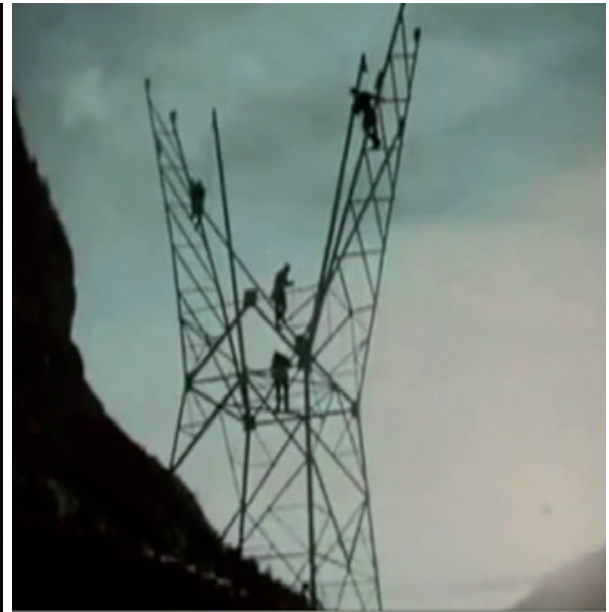

Tre fili fino a Milano (1958).
Con todo, aun sin negar la evidente impronta creativa que Ermanno Olmi dejó a su paso por la Sezione Cinema -aportación que se hace patente tanto en precisas elecciones argumentales, de puesta en escena y formales, como en dinámicas de trabajo-, creemos que las aproximaciones teóricas que se han centrado en el dibujo de la incipiente poética del cineasta (que son la gran mayoría) suelen pasar por alto todo el contexto en que estas películas surgieron: la práctica del cine industrial en un periodo determinado de la historia italiana moderna. Como intentaremos demostrar a continuación, las lógicas del cine industrial difieren en gran medida de las del cine de distribución convencional y, a la hora del análisis, tan o más importante que la delimitación de los rasgos estéticos de un filme corporativo -y su ocasional atribución a un auteur cinematográfico, como es el caso- es su inserción en un engranaje productivo y discursivo de naturaleza funcional, esto es, de utilidad respecto a unos objetivos de organización?.
[6] Para un examen de la (cambiante) poética de Olmi, recomendamos la lectura del ensayo de Adriano Aprà, «Le rinascite di Olmi» (en Adriano Aprà [ed.], Ermanno Olmi: Il cinema, i film, la televisione, la scuola [Venecia, Marsilio, 2003] pp. 11-20). El texto se tradujo al castellano para el libro Ermanno Olmi. Seis encuentros y otros instantes (véase Adriano Aprà, «Los renaceres de Olmi», en Carlos Muguiro [ed.], Ermanno Olmi. Seis encuentros $y$ otros instantes [Pamplona, Fondo de Publicaciones del Gobierno de Navarra, 2008], pp. 20-32). Meticulosos acercamientos españoles a las primeras obras de ficción del bergamasco, en particular a su trilogía del trabajo, los hallamos en Antonio Checa Godoy, «La belleza del trabajo. El cine de Ermanno Olmi», en Carmen Arocena (ed.), La ilusión de la belleza: actas del I Congreso Internacional de Estética Cinematográfica (Bilbao, Universidad del País Vasco, 4, 5 y 6 de junio de 2009), pp. 271-281, y en Juan José Caballero, «Ermanno Olmi», en Daniela Aronica y José Enrique Monterde (eds.), En torno al Nuevo Cine Italiano. Realismo y poesía (Valencia, IVAC, 2005), pp. 217-224. En todos estos textos se examina la producción industrial de Olmi-Edison centrándose en sus valores estéticos y expresivos, poniéndolos en relación con la filmografía posterior del bergamasco.

[7] El mismo Olmi declaraba en relación a su trabajo en la Sezione Cinema: «Gran parte de los documentales para la Edison (muchos de los que se finalizaban) no nacían de una inspiración poética [...] sino que eran funcionales respecto a un objetivo técnico y económico». En Jeanne Dillon, Ermanno Olmi (Florencia, La Nuova Italia - Il Castoro Cinema, 1985), pp. 14-15 (La traducción es nuestra). 
[8] La cita de Acland y Wasson proviene de la introducción a su libro Useful Cinema. Charles R. Acland y Haidee Wasson (eds.), Useful Cinema (Maine, Duke University Press, 2011), p. 2 (La traducción es nuestra).

[9] Véase, por ejemplo, Antonio Checa Godoy, «La belleza del trabajo. El cine de Ermanno Olmi».

[10] El Archivio Nazionale del Cinema d'Impresa, fundado en 2005 con sede en Ivrea (región del Piamonte), fue creado como una rama especializada del estatal Centro Sperimentale di Cinematografia (CSC) con el objeto de preservar, restaurar y difundir la actividad audiovisual realizada en Italia dentro del ámbito corporativo e industrial. Véase el canal de YouTube donde están alojados gran parte de sus fondos digitalizados, disponible en: <https://www. youtube.com/channel/UCIjXNCk3i5ewxUVGHwHNogg> (18/o1/2018).

[11] El Archivio del Cinema e della Comunicazione d'Impresa, sito en Castellananza (provincia de Varese, en Lombardía) y fundado en 1998, depende de la Universidad Carlo Cattaneo LIUC y de la Confindustria, la confederación nacional de la industria italiana. Véase su página web, disponible en: <http://www. archiviocinemaindustriale.it/> (18/01/2018).
Al mismo tiempo y, como ya hemos visto, un gran número de los filmes realizados bajo supervisión de Olmi en la Edison Volta presentan una serie de particularidades e innovaciones que los hacen de enorme interés frente a otros títulos, de la misma o de otras empresas, que priorizaban fórmulas narrativas o estéticas más convencionales o adaptadas a una retórica industrial estándar. Si, en afortunada expresión de Charles A. Acland y Haidee Wasson, el filme industrial «privilegia la función sobre la belleza», entendiendo esta última como los aspectos que más inciden en el esfuerzo estético, ¿qué ocurre cuando una película industrial pone en primer plano dicho esfuerzo estético, cuando parece privilegiar sus valores «artísticos» frente a los puramente "pragmáticos»? atención a la fuerte dimensión «artística» de la que muchas de estas películas hacen gala, pero no para entenderla como un fin en sí misma, sino como un factor en la creación de un discurso audiovisual que buscaba fomentar una serie de valores y comportamientos en y hacia el ámbito industrial.

Para ello, tomaremos como muestra tres películas del corpus Edison, en las cuales encontramos rasgos que muchos especialistas han destacado como comunes al cine posterior de Olmi: el mundo del trabajo y la captación atenta de la cotidianeidad y la idiosincrasia de los trabajadores ${ }^{9}$. Dichos rasgos no nos servirán para subrayar las preocupaciones autorales del cineasta bergamasco, sino para ponerlas en el contexto más amplio de los discursos que la Edison Volta en particular y el cine industrial en general favorecían en torno al mundo laboral y al obrero como ser productivo. Antes de lanzarnos al análisis dedicaremos, empero, unas páginas a caracterizar las lógicas del cine industrial como herramienta comunicativa.

\section{Cine industrial: definición, estrategias y metodología de análisis}

Partamos, con el propósito de concretar nuestro objeto de estudio, de la definición del cine industrial o empresarial como aquel financiado por compañías, en su mayoría grandes corporaciones, y que es utilizado como herramienta comunicativa dirigida tanto al interior del tejido institucional como al entorno que le rodea. En Italia, gran parte de este material está disponible gracias a la difusión que el Archivio Nazionale del Cinema d'Impresa (ANCI), en colaboración con diversas entidades, ha lanzado al mercado del DVD y, más tarde, ha colgado en la Red, en concreto en su canal de YouTube ${ }^{10}$. Otras instituciones, como el Archivio del Cinema e della Comunicazione d'Impresa, ofrecen parte de estos materiales y un completo catálogo on-line de la producción industrial del periodo, en el que se incluyen los cortometrajes facturados por la Sezione Cinema Edison Volta ${ }^{11}$. A pesar de las características propias que, en el ámbito de cada empresa, región, país o área geopolítica, puedan atribuirse a un corpus de filmes industriales, las teorizaciones en torno a uno de los grandes fenómenos de producción paralelos a lo que entendemos por cine comercial han buscado un marco teórico que englobe las diferentes muestras alrededor de una serie de parámetros definidos. 
La implantación de los esquemas industriales, más allá de las mencionadas peculiaridades con que se asienten en cada territorio - así, en Italia, habría que tener en cuenta el contexto histórico y social de consolidación democrática y apertura a la modernidad iniciadas tras la Segunda Guerra Mundial que, al final de los años cincuenta, cristalizarían en el llamado miracolo, época de fuerte bonanza económica-, tiende a la homogeneidad; de ahí que podamos pensar que los atributos con que se inviste a las diferentes manifestaciones del cine corporativo responderán a objetivos similares. La idea de que el cine industrial funciona como un engranaje al servicio de su matriz empresarial es la que más ha calado entre los estudiosos y es la que guiará nuestra aproximación al ambivalente caso de $\mathrm{Olmi}^{12}$. Partiremos, por tanto, de la premisa de que el análisis de cada filme industrial, al deberse este a las exigencias de un plan de comunicación corporativa, debe hacer especial hincapié en su contexto productivo y sus condiciones de uso, pues estos marcan indefectiblemente al texto, al objeto-película, de formas mucho más unívocas que en un filme mainstream. La apariencia final de una determinada película corporativa estará condicionada por una serie de variables. Adoptaremos la clasificación que Thomas Elsaesser propuso para estudiar individualmente cada filme industrial según un enfoque epistemológico de tres «A»: para su contextualización certera, hay que tener en cuenta: el Anlass, motivo por el que la película fue producida; el Auftraggeber, grupo, entidad o comisión que financió y encargó la realización de dicha película; y el Adressat, audiencia a la que va dirigido el filme en cuestión $^{13}$. El film industrial está fuertemente condicionado por su coyuntura previa, por el propósito con el que se realiza y por el/los destinatario/s a quien se dirige, por lo que tomará la forma que considere más oportuna para satisfacer y acomodarse a estas tres pautas.

Así, en primer lugar, y como en cierto modo ya habíamos apuntado, insistimos en la naturaleza del cine corporativo como cine útil en el sentido más literal del término. La utilidad puede ser practicada de puertas para fuera o para dentro; es decir, bien para controlar y mejorar procesos productivos o difundir ciertos discursos y prácticas dentro de la propia empresa, bien para promocionar y divulgar discursos e imágenes entre agentes ajenos a dicha empresa. Por otra parte, esto nos lleva a pensar en la naturaleza lábil del cine industrial que, en base a las exigencias ya desgranadas, adoptará las más diversas apariencias, formatos y canales de circulación. Formal y estéticamente, una película corporativa puede presentarse como spot publicitario, documental promocional, cinta de ficción, vídeo corporativo... Asimismo, su circulación, dependiendo del tipo de público que quiera convocar, puede restringirse al interior de la institución - bien para la formación técnica de cuadros empresariales, bien para su entretenimiento o para el fomento del espíritu corporativo- o abrirse al público externo, ya sea de otras empresas o de una audiencia indistinta cuyas simpatías por la entidad y sus productos quieren despertarse - dicha audiencia, a su vez, puede ser cinematográfica,
[12] Obsérvese el siguiente fragmento donde se define con, creemos, bastante precisión el cine industrial: «Examinamos un cine peculiar. No se trata de un cine de pura creatividad según el sentido imaginativo y estético del autor, sino que tiene que estar en función de unos objetivos de empresa, de las exigencias de unos contenidos y de los diferentes públicos a los que vaya destinado. Se sitúa dentro de las estrategias de comunicación de una empresa tanto para el interior como para el exterior». Tomado de Mariano Cebrián Herreros, Cine documental e informativo de empresa. 50 años de producción de Fernando López Heptener en Iberduero y NO-DO (Madrid, Editorial Síntesis, 1994), p. 21. El caso de Cebrián Herreros constituye uno de los escasos ejemplos de estudios del cine industrial en España, aquí aplicado a la trayectoria de Fernando López Heptener, uno de los máximos artífices del cine empresarial español.

[13] Thomas Elsaesser, "Archives and Archaelogies. The Place of Non-Fiction Film in Contemporary Media», en Vizenz Hediger y Patrick Vonderau (eds.), Films that Work: Industrial Films and the Productivity of Media (Ámsterdam, Amsterdam University Press, 2009), pp. 19-34. 
[14] Vizenz Hediger y Patrick Vonderau exponen en el volumen Films That Work: Industrial Films and the Productivity of Media que las funciones desempeñadas por el cine industrial, a pesar de la inherente variedad de sus manifestaciones, pueden agruparse en un modelo de «tres R»: Record, Rhetoric, Rationalization. Record correspondería a la «memoria histórica» de la empresa; Rhetoric, al registro de sus actividades presentes encaminado a crear la conocida como «imagen corporativa»; $\mathrm{y}$, por último, Rationalization, a la utilización de los mecanismos propiamente cinematográficos - velocidad $\mathrm{y}$ distancia focal variables, por ejemplo- en el mantenimiento y mejora de los procesos productivos. Estas tres funciones pueden solaparse y presentarse indivisibles dentro de un mismo film. Véase Vizenz Hediger y Patrick Vonderau, «Record, Rhetoric, Rationalization. Industrial Organization and Film», en Vinzenz Hediger y Patrick Vonderau (eds.), Films that Work: Industrial Films and the Productivity of Media (Ámsterdam, Amsterdam University Press, 2009), pp. 40-46. televisiva...- ${ }^{14}$. No es descartable, entonces, que una película industrial pueda adherirse a ciertas formas asociadas a un «cine de calidad», como es el caso de gran parte del corpus Olmi-Edison, siempre que ello resulte congruente con los objetivos de organización propuestos ${ }^{15}$.

El enfoque «funcionalista» del cine industrial que proponemos tiene como objetivo no solo desvelar el contexto productivo en que este corpus tuvo lugar, sino también exponer, a través del estudio de dicho contexto, las estrategias retóricas y los discursos a través de los que la industria se percibía y legitimaba a sí misma, los valores que transmitía y los roles que se adjudicaba en un momento social dado. Entender los filmes industriales como partes de una estrategia de comunicación corporativa significa abordar su papel como difusores de modelos de conducta, de pautas de organización específicas de la lógica empresarial o, dicho con otras palabras, «como interfaces entre discursos y formas de organización social e industrial ${ }^{16}$. De resultas del análisis de un filme o de un conjunto de filmes industriales, pueden extraerse poderosas conclusiones sobre los mecanismos y estructuras que rigen determinadas instituciones, organizaciones e incluso sociedades. La veta industrial pone en juego toda una serie de implicaciones sociales, económicas e históricas que quizás no se revelasen en toda su magnitud si solo prestásemos atención a la faceta creativa que estas películas puedan presentar. Cortometrajes como los que nos disponemos a examinar también difundían un conjunto de elementos discursivos muy representativos de las formas de gobierno puestas en práctica por las instituciones empresariales de la época, elementos estos que no tenían por qué coincidir con la visión de Olmi ${ }^{17}$.

[15] Dejando aparte el caso de Ermanno Olmi, de algún modo excepcional al tratarse de un cineasta que se formó como tal dentro de la propia empresa y que pasó después al circuito comercial y de autor, no era extraño que las firmas italianas de la época se sirviesen de directores más o menos reputados en los circuitos mainstream, ya fuese para asegurarse un grado óptimo de profesionalidad en el acabado de sus productos fílmicos o para granjearse una aureola de prestigio y calidad. Ejemplo de lo primero es la automovilística Fiat, que contrató al veterano y todoterreno Alessandro Blasetti para cortos publicitarios como Fiat 600 (1955), mientras que la petrolera ENI fue representativa de una política de «calidad cinematográfica» al enrolar para dirigir sus documentales promocionales a cineastas como Joris Ivens (L'Italia non è un paese povero [1960]) o Bernardo Bertolucci (La via del petrolio [1967]). A este respecto, véanse Marco Bertozzi, Storia del documentario italiano. Immagini e culture dell'altro cinema (Venecia, Marsilio Editori, 2008), pp. 138-146, y Paola Bonifazio, «United We Drill: ENI, Films and the Culture of Work», en Annali d'Italianistica (vol. 32, 2014), pp. 329-350.

[16] Vinzenz Hediger y Patrick Vonderau «Introduction», en Vinzenz Hediger y Patrick Vonderau (eds.), Films that Work: Industrial Films and the Productivity of Media (Ámsterdam, Amsterdam University Press, 2009), p. 11 (La traducción es nuestra). Autores como Paola Bonifazio profundizan más en la cuestión y estudian esta faceta del cine industrial a la luz del concepto foucaultiano de «gubernamentalidad». En investigaciones como «Work, Welfare, Biopolitics: Italian and American Film Propaganda in the Age of Neorealism», en The Italianist (vol. 31, n. ${ }^{\circ}$ 2, 2011), pp. 155-180, «United We Drill: ENI, Films and the Culture of Work» y en el libro Schooling in Modernity. The Politics of Sponsored Films in Postwar Italy (Toronto, University of Toronto Press, 2014), Bonifazio demuestra el rol de artefacto «gubernamentalizador», difusor de formas de (auto)control, poder y conocimiento, que ostentaban películas como las patrocinadas por los gobiernos de la Democracia Cristiana para publicitar sus políticas, las encargadas por los órganos de propaganda del Plan Marshall, o las producidas por corporaciones industriales, incluidas algunas de Ermanno Olmi. Para una definición de «gubernamentalidad», véase Michel Foucault, Security, Territory, Population. Lectures at the Collège de France 1977-1978 (Nueva York, Palgrave Macmillan, 2007), pp. 108-109.

[17] Es más, aun cuando algunos rasgos estilístico-formales presentes en los trabajos de Olmi para la Edison perviven en su cine posterior, estos se posicionan dentro de relatos cuyo discurso muestra una progresiva virulencia crítica contra la sociedad industrializada, la tecnologización del trabajo, la vida urbana y los conceptos de «progreso» y «crecimiento económico», discurso este que no pertenece a la producción Edison. Si la visión sobre el mundo urbano e industrial es ambivalente en El empleo, en películas como Un certo giorno (1968) o en títulos más recientes como Centochiodi (2007) o Terra madre (2009), la crítica desengañada y la búsqueda de otros modelos de vida se hacen patentes. 


\section{Análisis de tres cortometrajes industriales a. Consideraciones preliminares}

Es necesario hacer algunas aclaraciones sobre el corpus Olmi-Edison antes de proceder al microanálisis de tres de las piezas que lo conforman. De los cuarenta títulos que, a día de hoy, se conservan, los veintidós disponibles para su visionado público ofrecen algo más que la tradicional exégesis apuntada por autores como Aprà, Toffetti o Checa Godoy, esto es, la forja de un cineasta en ciernes que labra una poética basada en el realismo, la atención al factor humano, la creatividad y capacidad de improvisación... ${ }^{18}$ Cortos como Costruzioni meccaniche Riva (1957), Venezia città moderna (1958) o Il grande paese d'acciaio (1960) presentan otras modalidades enunciativas que contradicen punto por punto todas las características citadas ${ }^{19}$.

El visionado de todo el corpus disponible da, más bien, una idea de las diversas facetas y empeños de la Edison Volta, ya fuesen la construcción de embalses y estructuras aledañas, la implantación de filiales en otras sedes Venecia, Siracusa (Sicilia) -, la creación de colonias estivales, obras de asistencia social o escuelas de formación profesional o la celebración de actividades recreativas, a los que habría que añadir diversos cortos de difícil clasificación temática, casi todos relatos de ficción, que no tienen que ver -en principiocon el universo laboral, pero que parecen responder a la necesidad de obtener presencia y prestigio en espacios poco transitados por el cine industrial -entre otros, figurarían L'onda (1955), sobre un poema de D'Annunzio, galardonado con un premio gubernamental, o Il pensionato (1958), filmado para emitirse en televisión $-{ }^{20}$.

No resulta fácil, por ello, separar lo representativo de lo que no lo es y extraer una muestra pequeña que dé cuenta de la heterogeneidad del corpus. Solo un examen de gran extensión serviría para calibrar en toda su complejidad la filmografía que Olmi realizó y coordinó para la Edison. Por lo tanto, focalizaremos nuestro análisis en un aspecto discursivo concreto - ya que no representativo, sí muy significativo a nuestro entender-, a saber, la representación del obrero y del esfuerzo industrial en tres momentos distintos de su relación con la empresa: el tiempo de la actividad recreativa en $I I^{O}$ Raduno sciistico sociale all'Alpe Devero (1954), el tiempo del puro trabajo en Un metro lungo cinque (1961) y el tiempo de la jubilación - el tiempo fuera de la actividad laboral- en Il pensionato (1958). Según se ha comentado, el interés en el universo del trabajo y del trabajador ha sido señalado como una de las líneas maestras de la filmografía de Olmi. Sin embargo, como intentaremos demostrar, los discursos que prevalecen aquí encajan mejor con los valores propios

[18] Sergio Toffetti, director del ANCI, firma sobre el corpus Olmi-Edison un significativo texto titulado «La Nouvelle Vague al lavoro» («La Nouvelle Vague en el trabajo»), donde se argumenta que la gran innovación artística que se impondría en el cine italiano de los años sesenta y setenta provenía de ámbitos poco considerados por la crítica, como el cine industrial, a la vez que compara el caso de Ermanno Olmi con el de otros cineastas que hicieron sus pinitos en el ámbito corporativo, como Jean-Luc Godard o Alain Resnais. Este texto incidiría en la legitimación de una veta fílmica hasta ahora poco atendida por la cinefilia ortodoxa a través de la reivindicación unilateral de sus valores estéticos. Véase Sergio Toffetti, «Ermanno Olmi: La Nouvelle Vague al lavoro", en Benedetta Tobagi (ed.), I volti e le mani. Ermanno Olmi. Gli anni Edison. Documentari $e$ cortometraggi (1954-1959) (Milán, Giangiacomo Feltrinelli Editore, 2008), pp. 7-13.

[19] Por ejemplo, Costruzioni meccaniche Riva (1957) nos muestra el proceso de planificación y construcción de una turbina Pelton en los establecimientos de Riva S.p.A., empresa asociada a la Edison Volta. El cortometraje privilegia vistas pictóricas, microscópicas o grandiosas, siempre espectaculares, de la construcción de la turbina, y en ningún momento el elemento humano tiene una presencia importante. Corto disponible en el siguiente enlace: <https://www.youtube. com/watch?v=UEQkz8Ii2Io > (20/01/2018).

[20] Para una información más completa de todas estas películas, véanse las filmografías recogidas en el citado volumen de Adriano Aprà (Adriano Aprà, Laura Buffoni y Stefania Carpiecci, «Filmografia», en Adriano Aprà [ed.] Ermanno Olmi: Il cinema, i film, la televisione, la scuola [Venecia, Marsilio Editori, 2003], p. 330-356) y en el libro Il film industriale, editado con ocasión del festival de cine industrial de Monza, que reúne un elenco, que debemos entender muy completo, de las realizaciones de la Sezione Cinema Edison Volta (véase «Un decennio di succesi per la sezione cinema EDISON VOLTA», en Walter Alberti [ed.], Il film industriale [Milán, Scuola Tipografica Figli della Provindenza, 1962], pp. 139-146). 
de la empresa capitalista, como son la concepción moral del trabajo y de la productividad. En el recorrido que trazamos desde los espacios controlados por la empresa hasta los que, en principio, caen fuera de su jurisdicción -la vida retirada de los jubilados- veremos cómo la ideología empresarial invade y regula toda actividad de los sujetos representados.

Por otra parte, en esta selección ha primado la idea de analizar cortos pertenecientes a ámbitos de recepción distintos que, tal como hemos comprobado, desempeñan un importante papel en la forma final de los filmes. Esos ámbitos de recepción son las proyecciones internas de la empresa y las películas destinadas a públicos externos, ya sean en salas de cine o en pantallas televisivas. El modelo de destinatario, marcado por cada canal de circulación, condicionará las decisiones formales que articulan cada cortometraje.

Por último, el análisis de los cortometrajes pondrá de relieve la particular poética olmiana, así como sus notas diferenciales respecto a otras manifestaciones del cine industrial. Esas notas, en todo caso, deben aceptarse con cierta cautela en tanto que el primero de los cortometrajes a examen no despliega los rasgos definidos como olmianos -y debe observarse que su realización es paralela a la de dos filmes canónicos como La diga del ghiacciaio (1954) y La pattuglia del passo San Giacomo (1954)-. La inventiva y el esfuerzo artístico de los otros dos cortos serán, además, puestos en relación con las exigencias discursivas y productivas de la Edison Volta, para lo cual nos serviremos del enfoque metodológico propuesto por Elsaesser.

\section{b. II Raduno sciistico sociale all'Alpe Devero (1954)}

Este cortometraje de quince minutos, rodado con película de $16 \mathrm{~mm}$. en blanco y negro y producido a expensas de la hidroeléctrica Edison Volta, reviste gran interés por tratarse de uno de los pocos conservados del corpus Edison que se dirige a los cuadros internos de la empresa ${ }^{22}$. Por otra parte, rompe con la exégesis comentada más arriba según la cual los cortos olmianos se caracterizan por una concienzuda búsqueda artística y un replanteamiento de los modos

[21] Película disponible en el siguiente enlace: $<$ https://www.youtube.com/ watch? $\mathrm{v}=\mathrm{nHaSeYcVOUg}>$ (20/01/2018).

[22] La película no figura en ninguna de las filmografías olmianas manejadas, excepto en el catálogo del Archivio del Cinema e della Communicazione d'Impresa, lo que lleva a pensar que este trabajo no se incluía en los corpus destinados a exhibirse fuera de la compañía, y solo recientemente la labor archivística de empresas e instituciones lo ha sacado a la luz. habituales del cine industrial.

II ${ }^{o}$ Raduno sciistico sociale all'Alpe Devero. Trofeo dei caduti in guerra e sul lavoro (1954) refiere los pormenores de un torneo de esquí organizado y patrocinado por la empresa Edison Volta en la homónima zona montañosa durante las navidades de 1953. Después de unas imágenes introductorias de la ciudad de Milán engalanada para las fiestas, la narración, de formas claramente «reportajeadas» - voice over omnipresente, ausencia casi total de sonido ambiente, relato descriptivo, casi al modo de una crónica deportiva-, salta al torneo de esquí, con sus diferentes etapas y participantes, todos ellos asalariados de las diferentes sedes de la Edison Volta. El desfile de participantes realizando las pruebas de la competición se desarrolla con cierta monotonía, con posiciones y tiros de cámara repetidos incesantemente para rodar una misma acción realizada por diferentes esquiadores. Solo amenizan el conjunto la mú- 
sica extradiegética, compuesta por melodías de aires populares y cantos tradicionales de la montaña, y los comentarios, a veces jocosos y burlones, de la voice over masculina. Así, el plano de un esquiador que desciende rápidamente y en equilibrio inestable una loma se acompaña de la imitación de un murmullo de vértigo; las caídas, traspiés y demás percances en la nieve se remarcan con la voz del narrador, que chapurrea exclamaciones en dialecto como si parodiase a los competidores.

En la última parte del cortometraje, asistimos a la entrega de premios - con la participación del «Dottore Bobbio», director ejecutivo de la compañía [fig. 5] - en la que se habla en recuerdo de los «que ya no están con nosotros», en referencia a los caídos en la guerra y durante el trabajo - se alude a un fallecido competidor, «el inolvidable Natalino Proletti», seguramente un asiduo a este evento-. El último minuto de duración se consagra a una exposición de todo lo visto: volvemos a contemplar algunos planos de la competición esquiadora mientras la voice over concluye con estas significativas declaraciones: «Esto ha
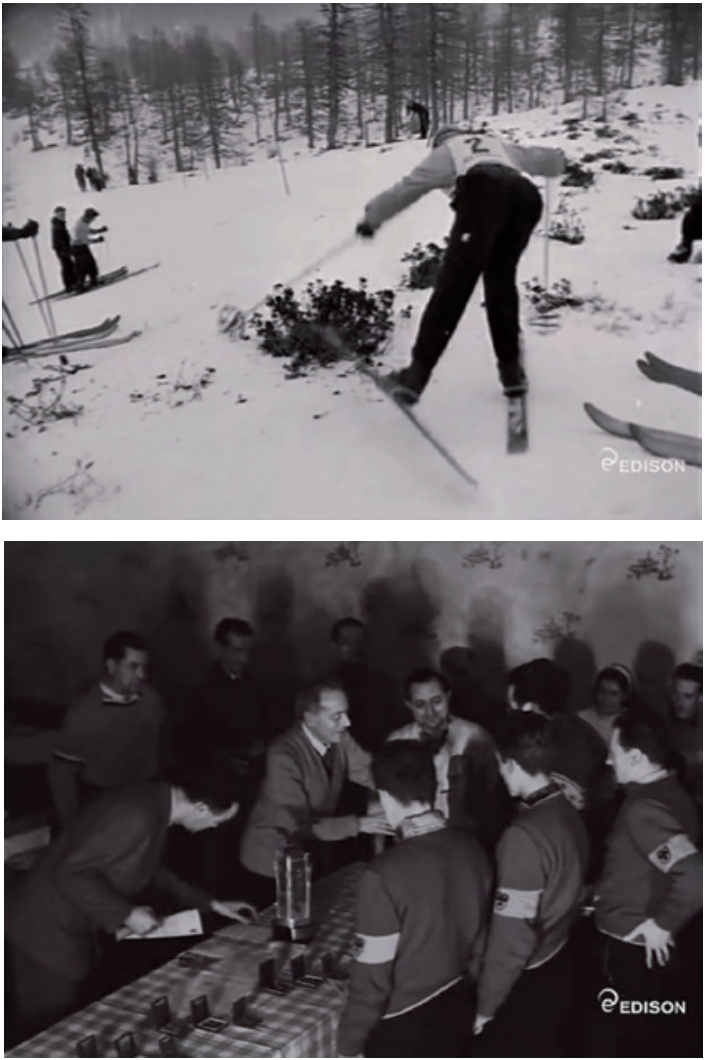

$I^{\circ}$ Raduno sciistico sociale all'Alpe Devero (1954). sido el segundo concurso de esquí en los Alpes Déveros, con sus campeones y no campeones, con sus vencedores y perdedores, pero, sobre todo, con valerosos muchachos que han luchado con buena actitud e inapelable lealtad».

La película no trasciende en sus formas el mero reportaje noticioso, pero es necesario entenderla dentro de su contexto empresarial para valorarla adecuadamente y no desdeñarla como la rutinaria muestra de un evento corporativo. El tono ligero y familiar que permea el conjunto se justifica por su público destinatario: los propios empleados de la compañía, algunos de los cuales formaban parte de la competición y se verían reconocidos en las imágenes cuando el cortometraje se proyectase en alguna reunión posterior. Las referencias a nombres y actitudes de los deportistas y de los miembros del comité organizador, así como las «bromas internas» imitando voces de algunos de los participantes, tienen su explicación en esta pretensión de prolongar, mediante el propio objeto-película, un ambiente de sana competitividad y camaradería que habría caracterizado el evento deportivo. La referencia en los premios y en la cabecera del filme a «los caídos en la guerra y el trabajo» refuerza la ligazón entre la empresa patrocinadora y el cuerpo de trabajadores, que ve reconocido el sacrificio de sus compañeros y, con el de ellos, el suyo propio. 
Es interesante la equivalencia trazada entre los caídos durante la guerra y en el trabajo, pues dibuja una línea que hermana a los muertos por defender la patria contra las fuerzas invasoras - el otrora aliado ejército alemán- con aquellos que dieron su vida en las construcciones de su empresa, fuentes estas de modernidad, riqueza y progreso según los discursos corporativos. El trabajo vendría a ser, por tanto, un servicio a la patria tan válido como el esfuerzo bélico. Se sella así una unión conceptual entre la recuperación política de la nación italiana y su resurgir económico favorecido por corporaciones como la Edison. El retrato de los trabajadores, aquí inmersos en una competición en principio ajena a su faceta laboral, como personas leales y esforzadas, siempre bien dispuestas a la fatiga en aras del progreso y la productividad, será una constante en la producción Edison, como tendremos ocasión de comprobar a continuación.

De este modo, el metraje serviría, en un primer momento, como estímulo para la cohesión de los trabajadores en torno a la empresa y su imagen corporativa: gracias a la filmación de actividades recreativas, Edison Volta multiplicaba su impacto y presencia en el imaginario de sus trabajadores, reunidos en torno al ideal del héroe anónimo y humilde, el que ante cualquier circunstancia sabe cumplir con su labor. Posteriormente, esta imagen de marca pervivirá como archivo histórico al conservarse y difundirse por otros canales -como ha hecho recientemente la actual firma heredera de la antigua hidroeléctrica al permitir colgar en Internet algunos de los cortos olmianos-.

[23] Película disponible en el siguiente enlace: <https://www. youtube.com/watch?v=c_hgZowxYig> (20/01/2018).

[24] Véase Adriano Aprà, Laura Buffoni y Stefania Carpiecci, «Filmografia», p. 332. La legislación cinematográfica italiana (en concreto, la Ley n. ${ }^{\circ}$ 897/1956) establecía un número de cincuenta premios trimestrales, otorgados por comisiones estatales, a cortometrajes de alto valor técnico y artístico. La cuantía de estos premios permitía amortizar, en gran medida, los costes de producción de las obras, que, además, obtenían una distribución normalizada, puesto que se proyectaban como complemento a un largometraje. Para más información sobre el estatus del cortometraje italiano del periodo, equivalente a ojos legales al documental, véase Marco Bertozzi, Storia del documentario italiano. Immagini e culture dell'altro cinema, pp. 123-127.

\section{c. Un metro lungo cinque (1961) ${ }^{23}$}

«Un metro tan largo como cinco», cortometraje de veintitrés minutos en color que documenta la construcción del gran embalse de Val di Lei, es el último trabajo de encargo que Olmi completa para la Edison Volta. A diferencia de $I I^{o}$ Raduno..., podemos apreciar el considerable esfuerzo productivo del filme en: su tiempo de realización, el equivalente a los tres años de la construcción de la presa más el periodo de posproducción; el uso espectacular del color; su amalgama de técnicas asociadas a lo documental y a la ficción; la multiplicidad de episodios mostrados; e, incluso, la disparidad de voces narrativas, aquí tres, una de ellas diegética y dos extradiegéticas.

La película fue concebida como un documental promocional, de relaciones públicas, destinado a salas comerciales y, por lo tanto, dirigido a un público indiferenciado. Efectivamente, además de ganar múltiples premios en festivales especializados, obtuvo el premio gobernativo para distribuirse como complemento al largometraje Leoni al sole (Vittorio Caprioli, 1961) ${ }^{24}$. Su estructura narrativa, completamente lineal, sigue la evolución en las tareas de construcción del embalse, desde su planificación hasta la inauguración posterior al fin de los trabajos.

Tras unos minutos de presentación en los que vemos, en encuadres velozmente montados, el trajín de la obra, las voices over del doblador Alfredo Danti 
y del reputado actor Romolo Valli introducen las circunstancias de construcción del embalse de la Val di Lei narrándonos de paso la historia del paraje, todo ello mostrado con dibujos y estampas animadas. Asistimos a las fases de diseño y a las primeras pruebas de laboratorio con modelos de cemento a escala reducida. Después, comienza la acumulación y el transporte del cemento, materia primordial del embalse. A continuación, se nos muestra la puesta a punto de las canteras, carreteras, barracones, comedores y demás instalaciones necesarias para la gran obra. En menos de cinco minutos se condensa un gran volumen de información gracias a un ágil montaje que combina breves encuadres fijos, travellings, panorámicas, grandes vistas generales, planos detalle y gráficos animados. Las grandes tomas muestran lo colosal del embalse, a la par que su magnificencia: «Aquí todo asume proporciones gigantescas», declara la voz de Valli; «un metro es tan largo como cinco, dicen los constructores de la presa».

Esta espectacularidad, la habitual en los modos del cine industrial italiano, se verá complementada por insertos semificcionales, pequeñas historias que ejercen de reverso del eje narrativo principal. Mientras las voices over desgranan las particularidades numéricas y las curiosidades de la construcción, seremos testigos de una serie de «números» preparados por Olmi y su equipo, con los que se nos acerca a la cotidianidad de los obreros contratados para la construcción. Es la voice over de Valli la que presenta a un viejo mayoral responsable de la manutención «aficionado a los discursos». Este personaje, entre entrañable y cómico, con sus tres intervenciones repartidas a lo largo del filme, supondrá un contrapeso, merced a sus dicharacheros parlamentos en dialecto bergamasco, a la carga informativa, más técnica y aséptica, de la trama central [fig. 6].

La llegada en grupo de los obreros, sus pausas laborales, la hora del rancho, sus paseos nocturnos, la detención de los trabajos durante el invierno, las charlas intrascendentes mientras se escucha la radio, se bebe un café, se dormita o se lee una novelita pulp [fig. 7]... Todo ello es captado con afán costumbrista y una pizca de humorismo, resaltado por las intervenciones del mayoral. La planificación más sosegada de estos episodios contrasta con el ritmo vivo impuesto a los tramos de construcción, en los que predomina una puesta en serie de las imágenes concisa y de contornos espectaculares [fig. 8].
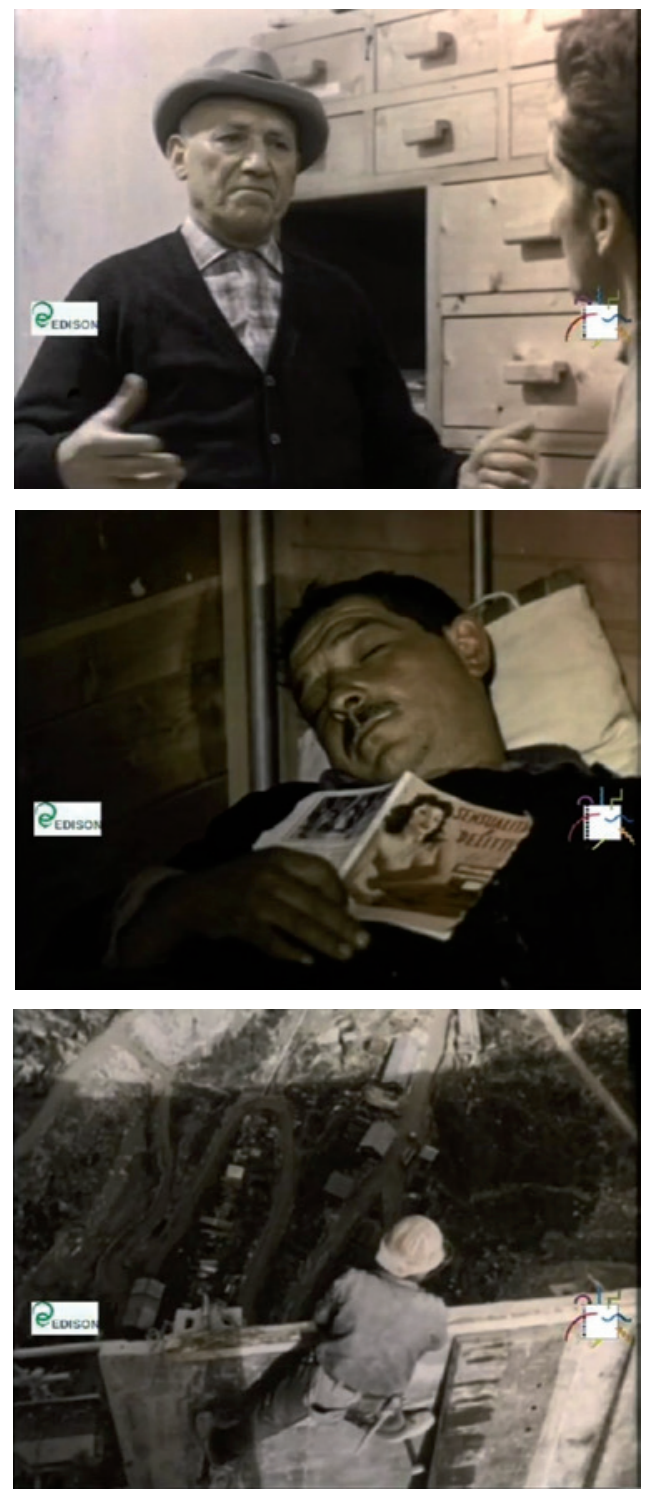

Figs. 6, 7 y 8. Un metro lungo cinque (1961). 
[25] Curiosamente, esta secuencia aparecerá reformulada por el propio Olmi en su película $U n$ certo giorno (1968). El protagonista de esta, un ejecutivo publicitario que ha atropellado a un campesino en un accidente automovilístico y ha salido indemne en el posterior juicio gracias a las triquiñuelas legales de su abogado, contempla la televisión con su mujer antes de irse a dormir. El televisor retransmite las últimas imágenes de Un metro lungo cinque (1961). Olmi crea así un contraste entre el optimismo de las imágenes televisadas con el ambiente de desencanto y derrota moral que exuda la escena final de Un certo giorno, al tiempo que marca distancias con el discurso industrial que tiempo atrás él ayudó a difundir.

[26] Para apreciar la singularidad de estos cortometrajes, recomendamos la comparación con otros trabajos más convencionales, producidos también para la Edison Volta, y que se ocupan de los mismos temas, como Toce 28 (Guido Guerrasio, 1954), disponible en: <https://www.youtube. com/watch?v=r7jzelkRnB8> (20/01/2018).

[27] El cruce de estos dos niveles narrativos encuentra paralelismo en la mezcla de elementos asociados a la ficción y al documental: las filmaciones en vivo de los procesos productivos, arquetípicas del documental tradicional, se imbricaban con tramas o esbozos de relatos plenamente reconstruidos, estrategia remitente al cine de ficción.

[28] No son pocos los autores que emparentan estos métodos con las poéticas neorrealistas, como Adriano Aprà («Primi approcci al documentario italiano», en Lino Miccichè [ed.], Studi su dodici sguardi d'autore in cortometraggio [Turín, Lindau, 1995], pp. 281-295) o Juan José Caballero («Ermanno Olmi», en Daniela Aronica y José Enrique Monterde [eds.], En torno al Nuevo Cine Italiano. Realismo y poesía [Valencia, IVAC, 2005], p. 218).
Los tres últimos minutos de metraje están dedicados a la finalización de los trabajos y a la inauguración del embalse, a la que asisten directivos e ingenieros de la Edison, representantes políticos como el democristiano Athos Valsecchi - al que oiremos un brevísimo extracto de su discurso- y todos los obreros, incluido el mayoral. Toca, por fin, a este dar su última perorata. Cuando, para su tristeza, todos se han marchado, el anciano pronuncia delante de unos pocos compañeros que han quedado en el barracón un emotivo parlamento mientras desfilan imágenes ya vistas del valle y de los operarios: «Mañana por la mañana nos despediremos todos; es más, puede que ni nos despidamos porque no tendremos nada que decirnos. Y la presa, que es un poco de todos nosotros, se quedará aquí. Y quien la venga a visitar ni siquiera pensará en todo lo que hemos hecho. Pero no importa. Lo sabemos nosotros y con eso basta». Al cesar el discurso, las imágenes de los trabajos continúan: el plano general de la explosión en una ladera, trabajadores manipulando martillos neumáticos en primer plano... conducen al fundido a negro final ${ }^{25}$.

Un metro lungo cinque juega en todo su metraje con los contrastes entre lo gigantesco y lo minúsculo, lo técnico y lo emotivo. Los comentarios over representan esta dualidad: la voz seca de Danti se encarga de los datos y cifras oficiales, de la información científica; el tono más aterciopelado de Valli se adapta mejor a los detalles sociológicos o llamativos. Las imágenes combinan la espectacularidad de los escenarios, reforzada por las emulsiones Ferrania y Eastmancolor, con la intimidad y delicadeza de las escenas, en su mayoría recreadas, de la vida en los barracones. Muchas veces, ambas vertientes chocan: una explosión hace derramar a un camarero un vaso de vino y caerse una radio; la cámara hace hincapié en las actitudes y rostros de los operarios que trabajan colgados a varios cientos de metros de altura.

Es justamente la atención por el factor humano el rasgo distintivo de la producción Olmi-Edison. Ya en sus primeras películas en $35 \mathrm{~mm}$., como $\mathrm{La}$ diga del ghiacciaio (1954), la narración bascula entre los hechos corporativos y la micro-vivencia de los subordinados ${ }^{26}$. Estas intrusiones o brechas en el usual tejido narrativo del cine industrial se irán profundizando conforme la Sezione vaya ganando prestigio. Manon finestra 2 (1956), Tre fili fino a Milano (1958) y, sobre todo, Un metro lungo cinque establecen una distancia cada vez mayor entre las informaciones técnicas y la propaganda corporativa respecto de las anécdotas y estampas de operarios, que pueden llegar incluso a erigirse en coprotagonistas del relato, como en el presente corto $^{27}$. La inclusión de la figura del trabajador escoraba parte de los cortos Edison hacia una representación realista con escasos antecedentes en la cinematografía industrial italiana, reforzada por decisiones como el uso de actores no profesionales, la capacidad de improvisación en el equipo técnico y artístico, la filmación cámara en mano, la inserción de sonido ambiente y diálogos recogidos en directo... ${ }^{28}$ Por otro lado, el juego con las diferentes voces narradoras puede leerse como una cierta ruptura con la tendencia enunciativa general del cine industrial italiano, casi siempre deudor de las formas del documental tradicional - de la moda- 
lidad expositiva, en palabras de Bill Nichols ${ }^{29}$-, en especial en lo relativo al uso de la voice over como principal instancia enunciadora - portadora unívoca del discurso corporativo-, a la que el resto de elementos fílmicos quedaban subordinados. El fraccionamiento de esta instancia rectora en dos variantes, además de su compartido protagonismo con un personaje diegético que, para rizar el rizo, acaba por erigirse en tercera voice over cuando asume el discurso de cierre - discurso que, además, reivindica la humilde perspectiva del obrero-, comporta una complejización de las retóricas industriales y un énfasis en las diferentes capas de realidad que subyacen a la aparentemente uniforme y triunfal hazaña corporativa.

Sin embargo, esto no nos debe hacer pensar que existía una impugnación de los discursos empresariales en estos filmes. Es cierto que la reivindicación de la dignidad y tenacidad del trabajo obrero, la captación de conversaciones y monólogos en dialecto, de gestos y comportamientos cotidianos, cumple no ya una exigencia de realismo, sino que introduce las idiosincrasias de un grupo humano tradicionalmente marginado del tecnificado y triunfalista cine industrial; pero también lo es que estas representaciones no resultaban problemáticas para la ideología empresarial que promovía los filmes: eran permitidas e incluso premiadas abundantemente ${ }^{30}$. Los rasgos que acercan Un metro lungo cinque a ciertos postulados neorrealistas no deben confundirse, por tanto, con una subversión de los modos hegemónicos del cine corporativo. El ensalzamiento de los humildes no ataca el sistema en que están inmersos ni denuncia sus, seguramente, muy precarias condiciones laborales ${ }^{31}$. El perfil del obrero que aquí se nos ofrece, personaje abnegado presentado de manera que el público de una sala de cine pudiese empatizar con él fácilmente, no cuestiona ninguna dinámica laboral ni las ideas sobre trabajo y progreso que emanaban de estos filmes.

La convivencia entre la gran historia corporativa y la humilde intrahistoria obrera sirve, entonces, no para negar la primera, sino para certificar la armonía entre la civilización industrial y el sustrato humano que la sostiene.

\section{d. Il pensionato $(1958)^{32}$}

«El jubilado» es un cortometraje de diez minutos, con guion de Ermanno Olmi y Walter Locatelli sobre argumento de este último - posterior coordinador de la Sezione Cinema tras la marcha de Olmi-, rodado en blanco y negro, que la Sezione Cinema coproduce junto con la RAI-TV (Radiotelevisione Italiana), que lo emitirá en su programa televisivo Tempo libero ${ }^{33}$. Se trata de uno de los raros ejemplos de cortometraje de ficción dentro del corpus Edison, aunque incorpora elementos asociados a los modos documentales, como luego veremos.

La historia, una suerte de fábula costumbrista, es harto simple. El jubilado Giuseppe Bonfanti (Piero Fanconti) vive en una barriada milanesa con su mujer, Maria (Mary Valente). Giuseppe, hombre bronco y malhumorado, se pasa
[29] Descripción del documental de modalidad expositiva en Bill Nichols, La representación de la realidad: cuestiones $y$ conceptos sobre el documental (Barcelona, Paidós Ibérica, 1997), pp. 68-72.

[3o] Aquí, la lista de premios: I Premio Copa de la Confindustria, I Premio a la dirección y Copa FONIT-CETRA al mejor acompañamiento musical en el II Festival del Film Industriale (Turín, 1961); II Premio asignado por la Confindustria en la II Rassegna Nazionale del Film Industriale (Venecia, 1961); Mención Especial en X Festival Internazionale di Trento (1961); I Premio a la Mejor Realización en el Festival Internacional del Film Industrial de Budapest (1961). Véase Adriano Aprà, Laura Buffoni y Stefania Carpiecci, «Filmografia», p. 332.

[31] En ningún momento del metraje se alude, por ejemplo, a mecanismos de solidaridad obrera como partidos o sindicatos. La convivencia entre los asalariados parece desenvolverse en un espacio de camaradería y compañerismo desideologizados.

[32] Película disponible en el siguiente enlace: <https://www. youtube.com/watch?v=Twh6_ ALdZ7c > (20/01/2018).

[33] El cortometraje formaba parte de un programa televisivo semanal cuyo target eran los trabajadores. Se habría emitido en la entrega n. ${ }^{\circ} 84$, en la primavera de 1959. Véase al respecto Adriano Aprà, Laura Buffoni y Stefania Carpiecci, «Filmografia», p. 330. 
los días asomado a su ventana mirando pasar los trenes por una vía cercana y riñendo a los niños que juegan en el patio vecinal y a dos jóvenes que intentan montar una máquina tipográfica en el garaje situado debajo de su apartamento [fig. 9]. La actitud del jubilado, según nos explican una voice over que ejerce de instancia narrativa omnisciente y un flashback que nos lo devuelve a sus tiempos de capataz en los gaseoductos lombardos, cuando era conocido como «El Polemista» - por su tendencia a «dictar sentencia sobre este o aquel asunto» $\mathrm{y}$ por las filípicas que daba a los empleados más jóvenes e inexpertos-, se debe a que, tras obtener el ansiado retiro, los planes de Giuseppe y Maria de volver a su pueblo natal se cancelan cuando el único hijo de ambos se casa. Esto empuja al viejo matrimonio a quedarse en Milán para ayudar a la joven pareja y ver a menudo a su futuro nieto. El presente anodino del anciano cambiará cuando se decide a ayudar a los jóvenes operarios que no consiguen arreglar su tipográfica. Tras bajar al garaje y dictaminar el fallo y las necesidades de arreglo de la máquina, Bonfanti se entusiasmará con su nueva tarea hasta el punto de no volver a su casa a dormir [fig. 10]. En una secuencia simétrica a la del inicio, en la que Bonfanti, desvelado por los ruidos del taller de abajo, se despertaba malhumorado a altas horas de la noche para reñir desde su ventana a los operarios, ahora Maria se levanta, pasada la medianoche, para conminar a su marido a
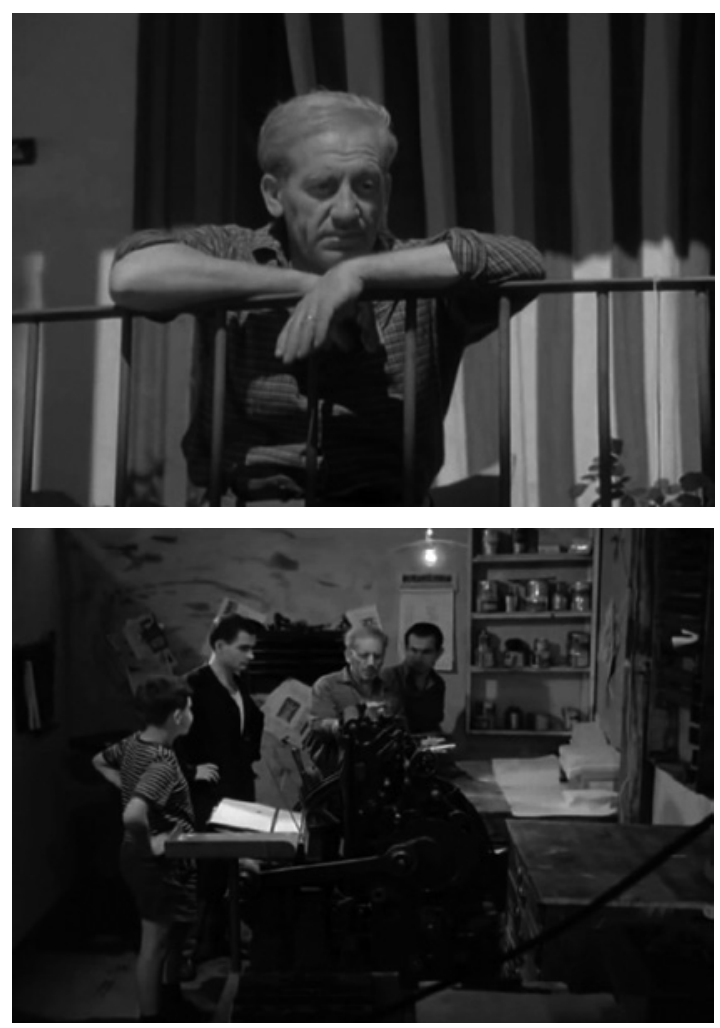

Figs. 9 y 10. Il pensionato (1958). irse a dormir. Bonfanti, con sus proverbiales malos modos, se asoma desde el garaje e insiste en quedarse a terminar la faena. Mientras él y su señora vuelven a sus respectivos puestos y la cámara se aleja en un lento travelling del escenario del patio vecinal, la voz narradora resume la moraleja del relato: «Y así, Giuseppe Bonfanti, el jubilado de las oficinas del gas, con su experiencia de mecánico veterano, será ayudante y guía de los dos jóvenes tipógrafos. Ya no lo veremos aburrido con los codos apoyados en la barandilla contando vagones de los trenes de mercancías que pasan, lentos y pesados, sobre el terraplén de la ferrovía».

Resulta interesante que una figura poco representada en el cine y la televisión de aquel entonces, como es un jubilado, y un ámbito completamente alejado de la lógica laboral, como es el de la vida cotidiana de un trabajador retirado, constituyan el interés de la sección comunicativa de una gran empresa. La necesidad de articular un relato que reuniese las preocupaciones del público objetivo del programa Tempo libero - trabajadores que encendían la televisión en, justamente, su tiempo de ocio- 
con las inquietudes creativas de la Sezione Cinema Edison Volta y los discursos arquetípicos del cine industrial encuentran una ejemplar formulación en esta breve pieza.

En ella, parece adivinarse parte del estilo que Olmi desarrollaría en su cine de ficción inmediatamente posterior. La ambientación en espacios cotidianos y de clase baja - un dormitorio, un balcón, un patio vecinal y un taller-, la elección de actores no profesionales que recitan sus diálogos en cerrado dialecto lombardo, la narración pausada y la economía de recursos expresivos -captación de acciones en planos largos, con profundidad de campo y estudiados movimientos de cámara, ausencia de música extradiegética y uso minucioso del sonido- hacen pensar en las técnicas desarrolladas en El empleo (Il posto, 1961). Todo ello remite a un modo de representación realista que Olmi y su troupe habían practicado, con variantes, en otros trabajos para la Edison.
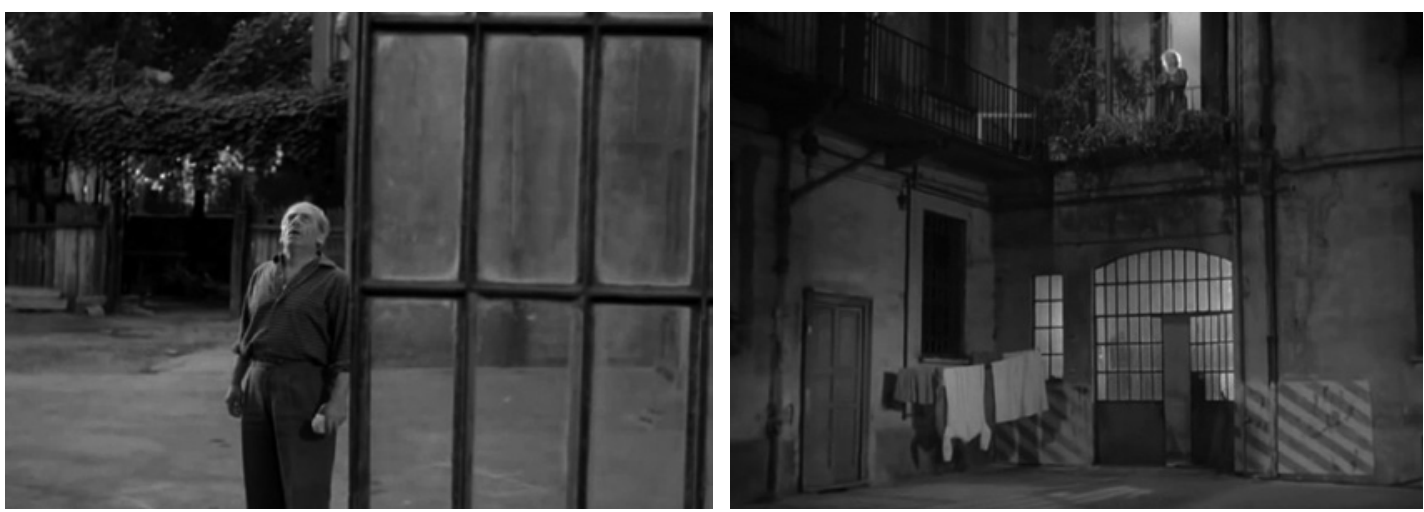

Figs. 11 y 12. Il pensionato.

Sin embargo, estas particularidades se combinan con otras que inclinan el conjunto hacia horizontes más didascálicos. Así, la voice over, que recita en «italiano normativo», portadora de toda la información referente a la diégesis y asociada a retóricas documentales -o más dirigistas-, comparte papel no solo con el naturalismo de la puesta en escena, sino con la voz interior del propio protagonista. Por otra parte, el flashback a los tiempos de Bonfanti como capataz, resuelto igualmente con enorme economía narrativa - apenas cinco planos y un solo escenario-, cumple la misma función clarificadora. La presencia de estos elementos y la tensión consecuente entre unos y otros parecen explicarse por la voluntad de imponer un contrapeso y una guía explicativa a un conjunto cuyo significado final, a pesar del realismo que lo recubre, no debe dar lugar a ambigüedades. Este mensaje final no debe ser otro que el de la preponderancia moral del trabajo.

$\mathrm{Y}$ es que, en contra de lo que propugnan otros analistas, caso de Ivelise Perniola, el aspecto que más resalta en Il pensionato no es ni la solidaridad obrera ni el canto a la redención, al valor de la experiencia o al entendimiento 
generacional -temas que, por supuesto, forman también parte del trasfondo de la película-, sino el moralismo en torno al obrero como ser productivo ${ }^{34}$. El protagonista se halla descentrado, vaciado, desde el momento en que pierde su estatus como empleado, como engranaje al servicio de la productividad. Solo encontrará sentido a su existencia -y el relato alcanzará su consecuente equilibrio-cuando se le presente la oportunidad de volver a ejercitarse en su especialidad. La historia de un individuo que solo es capaz de, literalmente, sentirse a gusto con su entorno cuando contribuye, aun a muy pequeña escala, a la lógica industrial puede y debe entenderse en un marco social en el que el rol que se exigía del hombre, especialmente del obrero, era el de ente al servicio del crecimiento económico ${ }^{35}$. Por tanto, Il pensionato vuelve a incidir en la representación del proletario como un ser que, a pesar de los rasgos humanizadores que se le asignan, no dejará de estar sometido a la exigencia del trabajo abnegado, trabajo que se impone como una suerte de paradigma presente incluso más allá de la vida laboral.

La Edison Volta contaba así, gracias a la retransmisión en la RAI, con un canal privilegiado para difundir su discurso, el de la omnipresencia y preponderancia moral del trabajo, en un envase en principio nada sospechoso de propagandismo.

\section{Conclusiones}

A la luz de los tres ejemplos examinados, podemos comprobar cómo las películas de la Sezione Cinema Edison Volta operaban dentro de un marco, el

[34] Si bien Perniola hace mención de este moralismo, parece minusvalorarlo respecto a los demás temas y valores estéticos del cortometraje. Véase Ivelise Perniola, «Grigio. Il pensionato», en Adriano Aprà (ed.) Ermanno Olmi: il cinema, i film, la televisione, la scuola (Venecia, Marsilio Editori, 2003), pp. 135-136.

[35] Compárese el contenido de este corto con el de otros filmes que abordan la vida de jubilados de forma mucho más problemática, como Umberto $D$ (Vittorio De Sica, 1951) o I giorni contati (Elio Petri, 1965).

[36] Elena Mosconi, «Il film industriale», en Raffaele De Berti (ed.), Il cinema a Milano dal secondo dopoguerra ai primi anni Sessanta, en Communicazioni Sociali (vol. XIII, n. ${ }^{\circ}$ 1-2, 1991), p. 72 (La traducción es nuestra). del cine industrial en Italia y la sociedad que lo englobaba. La atención a los discursos que difundían y a las formas en que venían facturados nos permite, además, entender la particularidad del caso de Ermanno Olmi dentro de este contexto. La apreciación estética del trabajo que el bergamasco realizó para la hidroeléctrica debe tener en cuenta cómo la dimensión creativa de algunas de sus películas -de nuevo: solo algunas; ya hemos visto que títulos como $I I^{o}$ Raduno... no responden enteramente a estas características- servía como factor adicional a la hora de propagar las bondades de la Edison ante diversos públicos. El innegable valor artístico de cortos como Il pensionato o Un metro lungo cinque no supone, como parecen asumir muchos analistas, un fin en sí mismo. Habría que considerarlo, más bien, como una herramienta estratégica -quizás, la más eficaz de todas - de relaciones públicas. La especialista en cine industrial italiano Elena Mosconi delinea muy agudamente la táctica que la Edison Volta seguía de cara a su comunicación externa.

A falta de productos específicos que promover - porque la promoción de la energía eléctrica se hace por sí sola- el documental industrial puede servir para incrementar el prestigio de la empresa y, sobre todo, para suscitar un movimiento de opinión favorable en torno a ella. Y, de este consenso, recordamos, tiene especial necesidad la Edison Volta, ya que la amenaza de la nacionalización $[\ldots]$ es constante ${ }^{36}$. 
La posibilidad de una nacionalización de la energía eléctrica, que se produjo en 1963 con la creación del conglomerado estatal Enel a cargo del ejecutivo presidido por Amintore Fanfani, ponía en peligro la independencia de la propia empresa como ente privado. En este sentido, la difusión de una promoción blanda, amable, de claros contornos artísticos, suponía un intento por labrarse una imagen pública benévola y conciliadora ${ }^{37}$.

Aproximaciones al cine corporativo que dan prevalencia a la novedad de formas y contenidos, o a la figura del realizador - como la llevada a cabo por el propio ANCI, que en su tarea de difusión del patrimonio fílmico industrial ha privilegiado los trabajos corporativos de cineastas ya canónicos, como Michelangelo Antonioni, Bernardo Bertolucci o nuestro Olmi- son necesarias en cuanto que recuperan una veta cinematográfica para hacerla del interés de una comunidad cinéfila que hasta entonces no le había prestado la necesaria atención ${ }^{38}$. No obstante, creemos que focalizar el interés de estos trabajos en sus aspectos estético-formales o en su relación con la particular poética de un sujeto creador supone quedarse con un detalle de una fotografía mucho más amplia. No negamos aquí -y es manifiesto en los análisis emprendidos- cómo Olmi va articulando una poética particular, tanto en el cine de empresa como en vistas a su futura puesta de largo en los circuitos del cine de autor. Con todo, en la ecuación entre autoría individual y naturaleza corporativa «de encargo», nos hemos situado en una posición intermedia -creemos que más justa y compleja - que, en vez de insistir en el «valor aurático» de los filmes de Olmi dentro del panorama del cine empresarial, remarque cómo la poética de un realizador, su carga de innovación estética, podía acomodarse a un discurso institucional ya asentado sin por ello llegar a cuestionarlo. Los estudiosos del cine industrial hacen notar cómo un examen exhaustivo de este corpus lleva a la conclusión de situar los valores estéticos de los filmes en un segundo plano. Cuando se da el caso de cortos como Un metro lungo cinque, donde esos valores exigen ser analizados detenidamente, debemos continuar mostrándonos cautos y no caer en una exégesis que aísle estos elementos y los separe de un contexto más grande que sobrepasa la mera atribución de excelencia estética o de autoría individual. En este sentido, hemos bajado a Olmi del pedestal del artista para situarle en el rol de empleado. Si acaso, era un «empleado modelo»: capaz no solo de cumplir los encargos de sus superiores, sino de hacerlo con soluciones altamente imaginativas que propulsaron al cine industrial de su momento a nuevos horizontes estéticos, lo que no debe llevarnos a engaño sobre la principal instancia discursiva tras dichos encargos.

Consideramos, entonces, que el análisis de las películas de utilidad ayuda a matizar y complejizar nociones como las del «cineasta-autor» o la del film como mero objeto artístico. Además, la propia exigencia funcional de este cine condiciona una hibridación estética que desdeña las fronteras, a nuestro parecer puramente convencionales, entre la ficción y el documental. Hemos podido comprobar cómo el corpus Edison utilizaba, de forma fresca y novedosa, recursos formales asociados a ambos terrenos y cómo estos alcanzaban un nuevo sentido en cuanto que se subordinaban a los discursos de los filmes industriales de los que formaban parte.
[37] La estrategia tuvo éxito en los propios circuitos de cine industrial, a juzgar por la cantidad de premios cosechados en certámenes especializados y por la influencia que los cortos de la Edison tuvieron en otros trabajos, como se puede observar en Sopraelevata, una strada d'acciaio (Valentino Orsini, 1963), de Italsider, o Buon lavoro, Sud (Giovanni Cecchinato, 1969), de Montecatini.

[38] El ANCI, en colaboración con otras entidades, ha promovido retrospectivas y sacado al mercado del DVD antologías dedicadas al trabajo industrial de cineastas como Bertolucci u Olmi. En el caso de este último, se edita en 2005 un DVD en la colección Real Cinema de la editorial Feltrinelli compuesto por las siguientes películas: Dialogo fra un venditore di almanacchi e un passeggiere (1954), La diga del ghiacciaio (1954), La pattuglia del Passo San Giacomo (1954), Manon finestra 2 (1956), Michelino $1^{a}$ $B$ (1956), Il pensionato (1958) y Tre fili fino a Milano (1958). La selección vino a apoyar, cuando no a crear, la visión canónica sobre la producción Edison: realismo, atención al factor humano, creatividad, hibridación entre modos documentales y ficcionales... Es significativo que otros cortometrajes del mismo periodo, como Costruzioni meccaniche Riva (1957) o Venezia, città moderna (1958), muy diferentes a las características apuntadas, no se incluyan en esta muestra. 
[39] Las publicaciones ya reseñadas han dado lugar a un importante congreso internacional en Frankfurt, en 2015 . Para más información, véase: $<$ http://www.films-that-work. $\mathrm{de} />(20 / 01 / 2018)$.

Espero que este estudio sirva como uno de los primeros acercamientos en español - ahí están los pioneros estudios de Mariano Cebrián Herreros- a un terreno todavía por explorar y teorizar y que solo algunas publicaciones extranjeras parecen empezar a tener en cuenta ${ }^{39}$. El cine industrial constituye un filón de estudios que involucra cuestiones como la relación entre instituciones y sociedad vehiculadas a través del audiovisual, las sinergias entre creadores e industrias, la naturaleza del denominado «trabajo de encargo», la consideración del cine y de otras prácticas visivas como agentes sociales y productivos portadores de determinados discursos... Espero, por lo demás, que la bibliografía e instrumentos teóricos recogidos en la primera parte de este artículo puedan ser provechosos a la hora de examinar toda una producción de cine útil que, sin ir más lejos, en España abarca corpus tan sugestivos como los fondos existentes en Filmoteca Española del Instituto Nacional de Industria (INI) o los catálogos de Iberdrola, entre otros. Un examen de sus particularidades - en gran parte debidas al contexto histórico y social- aportaría conclusiones muy interesantes que podrían sumarse a los detallados estudios emprendidos sobre las manifestaciones del cine útil en otras nacionalidades. En cualquier caso, la mera existencia de estos archivos certifica que lo que se entiende por cine comprende mucho más de lo que el espectador ve en los circuitos de exhibición habituales y que las formas del audiovisual son tan variadas como los usos sociales con que se las inviste.

\section{FUENTES}

Archivio del Cinema Industriale e della Comunicazione d’Impresa. Disponible en: <http:// archiviocinemaindustriale.it/> (18/01/2018).

Archivio Nazionale del Cinema d'Impresa, canal en YouTube. Disponible en: <https:// www.youtube.com/channel/UCIjXNCk3i5ewxUVGHwHNogg> (18/01/2018).

\section{BIBLIOGRAFÍA}

Acland, Charles R. y Wasson, Haidee (eds.), Useful Cinema (Maine, Duke University Press, 2011).

AlberTi, Walter (ed.), Il film industriale (Milán, Scuola Tipografica Figli della Provindenza, 1962).

APrÀ, Adriano, «Le rinascite di Olmi», en Adriano Aprà (ed.) Ermanno Olmi: Il cinema, i film, la televisione, la scuola (Venecia, Marsilio Editori, 2003), pp. 11-19.

-, «Primi approcci al documentario italiano», en Lino Miccichè (ed.), Studi su dodici sguardi d'autore in cortometraggio (Turín, Lindau, 1995), pp. 281-295.

-, BufFoni, Laura y CARPIECCI, Stefania, «Filmografia», en Adriano Aprà (ed.) Ermanno Olmi: Il cinema, i film, la televisione, la scuola, (Venecia, Marsilio Editori, 2003), pp. 330-356.

Bertozzi, Marco, Storia del documentario italiano. Immagini e culture dell'altro cinema (Venecia, Marsilio Editori, 2008).

Bonifazio, Paola, Schooling in Modernity. The Politics of Sponsored Films in Postwar Italy (Toronto, University of Toronto Press, 2014).

-, «United We Drill: ENI, Films and the Culture of Work», (Annali d'Italianistica, vol.32, 2014), pp. 329-350. 
-, «Work, Welfare, Biopolitics: Italian and American Film Propaganda in the Age of Neorealism», (The Italianist, vol. 31, $\mathrm{n}^{\mathrm{O}} 2$, 2011), pp. 155-180.

Caballero, Juan José, «Ermanno Olmi», en Daniela Aronica y José Enrique Monterde (eds.), En torno al Nuevo Cine Italiano. Realismo y poesía (Valencia, IVAC, 2005), pp. 217-224.

Cebrián Herreros, Mariano, Cine documental e informativo de empresa. 50 años de producción de Fernando López Heptener en Iberduero y NO-DO (Madrid, Editorial Síntesis, 1994).

Checa Godoy, Antonio, «La belleza del trabajo. El cine de Ermanno Olmi», en Carmen Arocena (ed.), La ilusión de la belleza: Actas del I Congreso Internacional de Estética Cinematográfica (Bilbao, Universidad del País Vasco, 4, 5 y 6 de junio de 2009), pp. 271-281.

Dillon, Jeanne, Ermanno Olmi (Florencia, La Nuova Italia - Il Castoro Cinema, 1985).

ElSAESSER, Thomas, «Archives and Archaelogies. The Place of Non-Fiction Film in Contemporary Media», en Vizenz Hediger y Patrick Vonderau (eds.), Films that Work: Industrial Films and the Productivity of Media (Ámsterdam, Amsterdam University Press, 2009), pp. 19-34.

FARASSINo, Alberto, «Un metro di pellicola è lungo cinque», en VV. AA., Ermanno Olmi, dal cinema industriale al cinema d'autore (Milán, Obraz Cinestudio y Montedison, 1984), pp. 3-6.

Foucault, Michel, Security, Territory, Population. Lectures at the Collège de France, 1977-1978 (Nueva York, Palgrave Macmillan, 2007).

Hediger, Vinzenz y Vonderau, Patrick, «Introduction», en Vinzenz Hediger y Patrick Vonderau (eds.), Films that Work: Industrial Films and the Productivity of Media (Ámsterdam, Amsterdam University Press, 2009), pp. 9-16.

-, «Record, Rhetoric, Rationalization. Industrial Organization and Film», en Vinzenz Hediger y Patrick Vonderau (eds.), Films that Work: Industrial Films and the Productivity of Media (Ámsterdam, Amsterdam University Press, 2009), pp. 35-49.

KezIch, Tullio «Storia naturale di un piccolo miracolo», en Benedetta Tobagi (ed.), I volti e le mani. Ermanno Olmi. Gli anni Edison. Documentari e cortometraggi (19541959) (Milán, Giangiacomo Feltrinelli Editore, 2008), pp. 65-71.

Moscon, Elena, «Il film industriale», en Raffaele De Berti, (ed.) Il cinema a Milano dal secondo dopoguerra ai primi anni Sessanta (Communicazioni Sociali, vol. XIII, n. $\left.{ }^{\circ} 1-2,1991\right)$, pp. 61-90.

Muguiro, Carlos (ed.), Ermanno Olmi. Seis encuentros y otros instantes (Pamplona, Fondo de Publicaciones del Gobierno de Navarra, 2008).

Nichols, Bill, La representación de la realidad: cuestiones y conceptos sobre el documental (Barcelona, Paidós Ibérica, 1997).

Perniola, Ivelise, «Grigio. Il pensionato», en Adriano Aprà (ed.), Ermanno Olmi: il cinema, i film, la televisione, la scuola (Venecia, Marsilio Editori, 2003).

Toffetri, Sergio «Ermanno Olmi: La Nouvelle Vague al lavoro», en Benedetta Tobagi (ed.), I volti e le mani. Ermanno Olmi. Gli anni Edison. Documentari e cortometraggi (1954-1959) (Milán, Giangiacomo Feltrinelli Editore, 2008), pp. 7-13.

Recibido: 30 de marzo de 2017

Aceptado para revisión por pares: 9 de junio de 2017

Aprobado para publicación: 17 de mayo de 2018 